\title{
What Do US Capitol Attack and the West's Covid-19 Death Rates Have in Common?
}

\begin{abstract}
Philosophical concepts can help us to understand key historical moments. The storming of Capital Hill in America and the Covid-19 death rates in the West highlight a different balance between "rights" and "responsibilities" when compared to Eastern societies.
\end{abstract}

At the end of the day, the root cause of many of the social and political problems we face is the failure to understand the real meaning of key philosophical concepts.

I write these words with some personal satisfaction. Fifty years ago, in 1971, when I graduated from the University of Singapore with a Bachelor of Arts in philosophy, some of my friends and family members secretly believed that I had wasted four good years of my life studying useless things.

Yet, as recent developments have shown, a failure to understand key philosophical concepts can lead to a large amount of human suffering and social and political turmoil.

Two surprising recent negative developments will be studied by historians for decades, if not centuries, to come. The first is the remarkable failure of the most advanced societies in our world, especially the United States and several European Union members, to lower the death rate from Covid-19 in their societies.

The second was the storming of the US Capitol on Jan 6. Both these developments are a result of a failure to understand how key philosophical concepts cannot be understood in isolation.

Future historians will certainly be astonished to see the great disparity in the death rates from Covid-19 between leading Western societies and East Asian societies. The gap is enormous.

Originally published in The Straits Times, Feb 2, 2021 


\section{Disparity in Societies}

So what explains this great disparity in death rates? The answer is surely complex. One root cause, however, has been the insistence of Western societies to emphasize "rights" while Asian societies focus on both "rights and responsibilities".

One reason why casualties from Covid-19 have been much higher in many Western countries is that citizens emphasize their "right" not to wear masks while never mentioning their "responsibility" to wear masks to save lives of fellow citizens. Fortunately, in most Asian societies, there is a greater acceptance of such responsibilities. This is why underlying philosophical assumptions are so important for social well-being.

I know from direct firsthand experience that many Western societies are reluctant to give equal importance to "rights" and "responsibilities". In 1998, the United Nations had a special session to commemorate the 50th anniversary of the adoption of the Universal Declaration of Human Rights (UDHR).

The UDHR is a truly moving and inspiring document. As human beings, we should worship and cherish it. Thanks to it, human rights standards in the world have improved significantly since it was launched in 1948, as documented, for example, in chapter “Asia, Say No to NATO” of psychologist Steven Pinker's book, Enlightenment Now.

\section{Emphasizing Responsibilities}

Yet, for centuries, Western and Asian philosophers have also emphasized the equal importance of "responsibilities". Economist and philosopher Friedrich Hayek, in The Constitution Of Liberty, states that "liberty and responsibility are inseparable".

Philosopher and Holocaust survivor Victor Frankl said: "Freedom, however, is not the last word. Freedom is only part of the story and half of the truth. Freedom is but the negative aspect of the whole phenomenon whose positive aspect is responsibleness. In fact, freedom is in danger of degenerating into mere arbitrariness unless it is lived in terms of responsibleness. That is why I recommend that the Statue of Liberty on the East Coast be supplemented by a Statue of Responsibility on the West Coast."

Fortunately, many leading statesmen of the world, led by the legendary former German chancellor Helmut Schmidt, decided to draft a "Universal Declaration of Human Responsibilities" to accompany the UDHR. Indeed, Mr Schmidt drafted such a declaration, which was then endorsed by several other global statesmen, including Mr Malcolm Fraser, Mr Lee Kuan Yew, Mr Pierre Trudeau and Mr Mikhail Gorbachev.

Mr. Schmidt's declaration was drafted in 1997. The perfect opportunity to have launched this Universal Declaration of Human Responsibilities was when the UN celebrated the 50th anniversary of the Universal Declaration of Human Rights. Since the West believes in the virtues of free speech and open debates, I thought that 
Western governments and non-governmental organizations would support a free and open discussion of Mr Schmidt's initiative. Instead, they mounted a strong campaign to suppress all discussions of the document. I know that all this happened. I was personally present and saw all this with my own eyes.

Two decades after this suppression of the discussion of responsibilities, the time has come for the West to make a massive U-turn away from its prevailing ideology of emphasizing rights only, without giving equal emphasis to equivalent responsibilities. Such a U-turn will save lives. Indeed, many lives lost to Covid-19 could have been saved.

The second shocking development was the storming of the US Capitol last month. What was the fundamental underlying cause of the anger displayed by the predominantly white working classes on that day? One clear answer is that a "sea of despair" has emerged among white working classes in America, which Nobel laureate in economics Angus Deaton and his wife, economist Anne Case, have documented well in their book, Deaths Of Despair And The Future Of Capitalism.

This sea of despair is also a result of failure to understand some key philosophical concepts. In the US, for example, most politicians and pundits emphasize only the importance of "freedom". Yet, philosophers have always used the term "freedom and equality" together.

The best proof of this is provided by American philosopher John Rawls. In his classic book, A Theory Of Justice, he emphasizes that two principles of justice go hand in hand. The first principle emphasizes individual liberty. Yet, the second principle emphasizes that any inequality that arises from "most extensive basic liberty" must nonetheless result in a society that works to "everyone's advantage".

Unlike the concept of strict egalitarianism, which calls for the allocation of equal material goods to all members of society, Dr. Rawls' principle allows for inequalities if it helps the bottom $10 \%$ improve their lives.

This is what happened in the US for many decades, from the 1950s to 1970s. Yet, from the 1980s, the incomes and standard of living of the bottom 10\%, indeed bottom 50\%, have stagnated or declined. The result has been the "sea of despair", which is the result of ignoring key philosophical precepts. And, in turn, the "sea of despair" has generated 74 million votes for Mr Donald Trump and, when he lost, the violent storming of the US Capitol.

In short, when we see societies in trouble, we should not just focus on personalities and events. We should take a deep dive and try to discover the underlying structural causes.

In so doing, we will often discover that the structural cause is a failure to understand the direct and necessary correlation between key philosophical concepts, like those between rights and responsibilities and between freedom and equality. 
Open Access This chapter is licensed under the terms of the Creative Commons AttributionNonCommercial-NoDerivatives 4.0 International License (http://creativecommons.org/licenses/bync-nd/4.0/), which permits any noncommercial use, sharing, distribution and reproduction in any medium or format, as long as you give appropriate credit to the original author(s) and the source, provide a link to the Creative Commons license and indicate if you modified the licensed material. You do not have permission under this license to share adapted material derived from this chapter or parts of it.

The images or other third party material in this chapter are included in the chapter's Creative Commons license, unless indicated otherwise in a credit line to the material. If material is not included in the chapter's Creative Commons license and your intended use is not permitted by statutory regulation or exceeds the permitted use, you will need to obtain permission directly from the copyright holder.

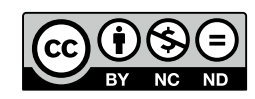

